\title{
Membangun Rasa Percaya Diri Remaja Putri Di Panti Asuhan Aisyiyah Kota Barat Surakarta Tahun 2019
}

1. Dra.Sri Hartini,M.Pd, 2. Dr.Hera Heru Sri Suryanti, S.Pd.,M.Pd. Fakultas Keguruan Dan IImu Pendidikan Universitas Slamet Riyadi Surakarta

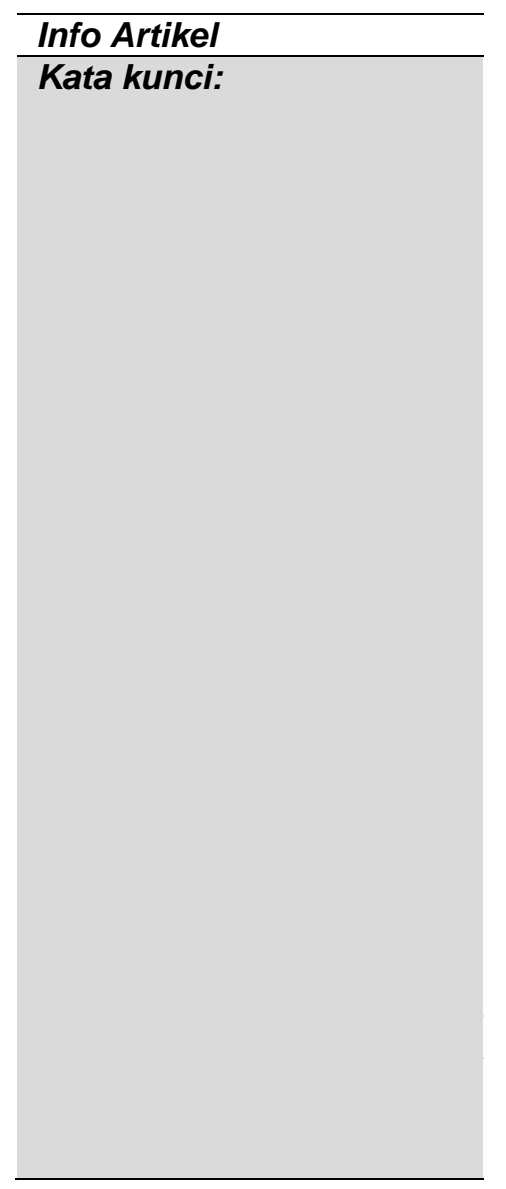

\begin{abstract}
Pengabdian pada Masyarakat ini bertujuan untuk menumbuhkembangkan rasa percaya diri para remaja putri di Panti Asuhan Aisyiyah Kota Barat Surakarta. Rasa Percaya Diri diawali dengan adanya konsep diri dan akan mempengaruhi rasa harga diri seseorang. Kosep Diri adalah pandangan dan perasaan kita tentang diri kita. Persepsi tentang diri ini dapat bersifat social, psikologis dan fisis. Selanjutnya Rasa Percaya Diri adalah kepercayaan terhadap kemampuan diri sendiri. Sedangkan Rasa Hatga Diri adalah rasa seberapa berharga diri sendiri dalam lingkungannya. Untuk itulah sangat penting membangun Rasa Percaya Diri di kalangan remaja putri Panti Aauhan Aisyiah yang secara social-ekonomi sangat bergantung kepada kedermawanan sesama manusia, agar perkembangan mereka dapat optimal dan terbebas dari rasa rendah diri (minder). Metode yang digunakan dalam kegiatan ini adalah Penyuluhan ,Konseling Kelompok, Simulasi dan Pendampingan. Dari kegiatan tersebut dapat diperoleh informasi adanya keberanian mengemukakan pendapat tentang pemilihan studi lanjut dan kekhawatiran tentang pembeayaannya. Selanjutnya kekhawatiran tersebut dapat dihilangkan oleh para remaja putri setelah diberikan informasi adanya berbagai jenis beasiswa yang disediakan oleh universitas Slamet Riyadi dan pentingnya pe.ngembangan diri untuk menggapai cita-cita.
\end{abstract}

\section{PENDAHULUAN}

\section{Analisis Situasi:}

Pengabdian Masyarakat ini diperuntukkan bagi Remaja Putri di Panti Asuhan Aisyiyah Kota Barat Surakarta. Di Panti ini mereka juga mendapat kesempatan mengikuti pendidikan formal seperti halnya anak-anak lain seusianya hanya saja mereka tidak pulang ke rumah namu ke Panti.

Remaja merupakan salah satu periode dalam perkembangan yang memerlukan perhatian khusus karena masa Remaja merupakan masa Pancaroba dari usia Anak-anak ke masa Remaja dan masa Dewasa. Pada masa ini dapat dilihat beberapa cirri khas dan menonjol baik dalam pertumbuhan biologis seperti munculnya jakun pada remaja pria, membesarnya bagian tubuh tertentu pada remaja wanita maupun dalam perkembangan psikologisnya seperti labilnya emosi, terbangunnya solidaritas yang kuat dalam pertemanan, mulai adanya ketertarikan pada lawan jenis, mulai tidak mau diperlakukan sebagai anak-anak lagi, dan adanya keinginan untuk dilibatkan dalam pengambilan keputusan.

Kondisi perkembangan seperti labilnya emosi memiliki kadar dan derajat yang berbeda-beda, salah satunya tergantung pada lingkungan dimana Remaja itu tinggal. Dalam konteks ini, tinggal di lingkungan Panti dapat memberikan dampak tertentu pada perkembangan rasa percaya diri remaja di antaranya munculnya pertanyaan mengapa harus hidup di panti dan tidak di dalam keluarganya seperti teman-teman lain di sekolahnya, kendatipun hal ini tidak selalu diungkapkan.Pertanyaan ini perlu segera mendapatkan jawaban agar tidak mempengaruhi perkembangan rasa percaya diri 
mereka sehingga menciptakan rasa minder yang akan berpengaruh terhadap pengembangan diri mereka.

Berdasar kondisi di atas maka Tim Pengabdian kepada Masyarakat prodi BK FKIP UNISRI terpanggil untuk memberikan penyuluhan akan pentingnya membangun rasa percaya diri pada remaja putri di Panti Asuhan Putri Aisyiyah Kota Barat Surakarta.

2. Identifikasi Masalah:

a.Remaja Putri di Panti Asuhan Aisyiyah terdiri dari usia Pra-Remaja dan Remaja

b.Remaja Putri di Panti Asuhan Aisyiyah bersekolah di Sekolah Umum di luar panti.

c.Adanya beberapa remaja yang sangat tertutup dalam berkomunikasi.

d.Perlunya penyuluhan untuk membangun rasa percaya diri sehingga akan memperlancar

komunikasi mereka di manapun mereka berada tanpa ada rasa minder.

3. Rumusan Masalah:

Bagaimana membangun rasa percaya diri pada Remaja Putri di Panti Asuhan Aisyiyah Kota Barat Surakarta?

4.Tujuan Kegiatan:

Tujuan kegiatan ini adalah untuk membangun rasa percaya diri pada Remaja Putri di Panti Asuhan Aisyiyah Kota Barat Surakarta.

\section{Target Dan Luaran}

a. Target: Terbangunnya Rasa Percaya Diri pada Remaja Putri di Panti Asuhan Aisyiyah Kota Barat Surakarta.

b. Luaran: Artikel di Jurnal Adiwidya

\section{METODE PELAKSANAAN}

\section{Sasaran / Khalayak:}

Khalayak sasaran yang dianggap strategis Remaja Putri di Panti Asuhan Aisyiyah Kota Barat Surakarta.

\section{Prioritas Masalah:}

Apa, mengapa, dan bagaimana .membangun rasa percaya diri pada Remaja Putri di Panti Asuhan Aisyiyah Kota Barat Surakarta.

\section{Metode Kegiatan:}

Metode yang digunakan dalam kegiatan ini adalah: Penyuluhan, Konseling Kelompok, Simulasi ..dan Pendampingan.

a. Penyuluhan digunsksn untuk menyampaikan konten-konten Rasa Percaya Diri.

b.Konseling Kelompok digunakan untuk memberikan bantuan alternative solusi masalah sejenis yang dihadapi para remaja putri.

c. Simulasi digunakan untuk memperjelas konten melalui pemberian peragaan.

d.Pendampingan digunakan untuk menjamin keberlanjutan pembentukan dan penguatan rasa percaya diri di kalangan remaja putri Aisyiyah Kota Barat Surakarta.

\section{HASIL YANG DICAPAI DAN PEMBAHASAN}

Hasil yang dicapai dalam kegiatan Pengabdian kepada Masyarakat ini adalah:

1. Adanya temuan bahwa faktor utama penyebab rasa minder di kalangan remaja putri di panti asuhan Aisyiyah terletak pada kemampuan ekonomi mereka.

2. Terjadinya perubahan dari rasa rendah diri atau rasa minder ke arah terbangunnya rasa percaya diri pada remaja putri di panti asuhan Aisyiyah Kota Barat Surakarta setelah mereka memahami perspektif pembeayaan perkuliahan di Perguruan Tinggi.

Rasa Percaya Diri diawali dengan adanya konsep diri dan akan mempengaruhi rasa harga diri seseorang. Kosep diri didefinisikan oleh William D.Brooks sebagai pandangan dan perasaan kita tentang diri kita. Persepsi tentang diri ini dapat bersifat social, psikologis dan fisis ( Jalaluddin Rakhmat,2011:98 ), sedangkan Rasa Percaya Diri adalah kurangnya kepercayaan kepada kemampuan sendiri. Maxwell Maltz berpendapat bahwa untuk meningkatkan rasa percaya diri, maka menimbulkan konsep diri yang sehat menjadi perlu (Jalaluddin Rakhmat,2011:99). Rasa Harga Diri 
merupakan hasil penilaian diri kita oleh diri sendiri tentang seberapa berharganya diri kita ini. Dengan demikian Konsep Diri yang sehat merupakan dasar bagi pengembangan rasa percaya diri dan rasa harga diri.

Remaja merupakan pribadi yang unik. Pendampingan terhdap para remaja khususnya pemberian perhatian dan kasih sayang perlu selalalu dilakukan secara terus menerus. Kurangnya perhatian dan kasih sayang kepada remaja dapat menimbulkan berbagai akibat seperti kenakalan remaja (Djamaludin Ancok, 2004: ) ataupun sebaliknya rasa minder. Jujun S.Suriasumantri menyatakan bahwa Pendidikan sebagai ilmu terapan yang mengaplikasikan 3 (tiga) ilmu sekaligus yakni: Psikologi, Sosiologi dan Antropologi sangat diperlukan dalam memecahkan masalah-masalah kependidikan (Mulyono Abdurrahman,1999:19) termasuk masalah perkembangan pribadi seseorang. Untuk itu penyuluhan sebagai salah satu bentuk pendidkan diharapkan dapat menjadi wahana perhatian dengan memberikan perspektif pentingnya membangun rasa percaya diri kepada remaja putri di Panti Asuhan Aisyiyah Kota Barat Surakarta..

Dari kegiatan pengabdian masyarakat tersebut dapat diperoleh informasi adanya keberanian mengemukakan pendapat tentang pemilihan studi lanjut dan kekhawatiran tentang pembeayaannya. Selanjutnya kekhawatiran tersebut dapat dihilangkan oleh para remaja putri setelah diberikan informasi adanya berbagai jenis beasiswa yang disediakan oleh universitas Slamet Riyadi dan pentingnya pe.ngembangan diri untuk menggapai cita-cita. Selanjutnya perlu adanya kerjasama secara continue antara Universitas Slamet Riyadi dengan Panti Asuhan Aisyiyah Kota Barat Surakarta dalam rangka pengembangan pribadi remaja putrinya melalui program layanan Bimbingan dan Konseling dengan pendampingan dalam hal pemberian penyuluhan dan konseling kelompok terkait perpektif cita-cita dan masa depan para remaja putri di panti asuhan Aisyiyah Kota Barat Surakarta agar rasa percata dirinya semakin kuat.

\section{REFERENCES}

Djamaludin Ancok,2004. Psikologi Terapan.Yogyakarta:Darussalam.

Jalaluddin Rakhmat,2011. Psikologi Komunikasi. Bandung Rosdakarya.

Mulyono Abdurrahman,1999 . Pendidikan Bagi Anak Berkesulitan Belajar. Jakarta Rineka

Cipta 